\title{
Mısır-mısır pası uyumlu interaksiyonunda ekspresyonu değişim gösteren genlerin DDRT-PCR analizi
}

\section{DDRT-PCR analysis of the expressional modulation showing genes in the maize- maize rust compatible interaction}

\author{
Hatice ÇILKOLĐ, Mehmet Ali SÜDÜPAK(D) \\ Yozgat Bozok Üniversitesi Fen-Edebiyat Fakültesi Biyoloji Bölümü, 66100 Yozgat \\ Sorumlu yazar (Corresponding author): M. A. Südüpak, e-posta (e-mail): msudupak@hotmail.com \\ Yazar(lar) e-posta (Author e-mail): haticecilkol@gmail.com
}

MAKALE BİLGİṠ

Alınıs tarihi 20 Ocak 2020

Düzeltilme tarihi 26 Mayis 2020

Kabul tarihi 26 Mayıs 2020

\section{Anahtar Kelimeler:}

Zea mays

Puccinia sorghi

Uyumlu interaksiyon

Gen ekspresyonu

RT-qPCR

\begin{abstract}
ÖZ
Bitki-mikrop interaksiyonlarında ekspresyonu değişim gösteren genlerin tanımlanması, konukçu direnci ve duyarlılığında gerçekleşen fizyolojik değişimler ve bunlardan sorumlu genetik faktörler ve mekanizmalar hakkında değerli bilgiler sağlamaktadır. Mısır (Zea mays) ve mısır pası (Puccinia sorghi) uyumlu interaksiyonunda gerçekleştirdiğimiz çalışmada, ekspresyonu değișim gösteren 98 transkript derivativi fragment (TDF) tanımlanmıștır. Klonlanarak sekans karakterizasyonu yapılan 72 TDF ile gerçekleştirilen GenBankası taramaları, münferit etiketler için bir veya daha fazla benzer kayıt bulunduğunu göstermektedir. Genel olarak, TDF'lerin yaklaşık yarısının fonksiyonu bilinen genlerin sekanslarına benzer olduğu ve bunların önemli bir bölümünün bitki-patojen interaksiyonlarında ekspresyonu değișim gösterenler oldukları tespit edilmiștir. Bunlar arasında, karbonik anhidraz, Bip2, An2, ARP ve ASR3 proteinlerini kodlayan genlere benzerlik gösteren TDF'ler bulunmaktadır. TDF'lerin kalan bölümü, diğer stres yanıtlarıyla ilgili olanlar ve karakterize edilmemiș/hipotetik protein kodlayan sekanslara benzerlik göstermektedir. ZmBip2, ZmCA, ZmcALDH, ZmARP ve ZmARPP3 genleri için RT-qPCR primerler tasarlanarak kontrol ve infekte materyalde ekspresyon teyitleri yapıldı. $Z m C A$ hariç, diğerlerinin tespitlerinde gözlenen ekspresyon değişimleri doğrulandı. Sinırlı sayıda TDF çalışılmış olmakla birlikte, belirli fonksiyonlarla ilişkili olanlarla birlikte fonksiyonu bilinmeyenler, çalışılan patosistem uyumlu interaksiyonunda ekspresyonu modülasyon gösteren genler olarak tanımlanmıştır.
\end{abstract}

\section{ARTICLE INFO}

Received 20 January 2020

Received in revised form 26 May 2020

Accepted 26 May 2020

\section{Keywords:}

Zea mays

Puccinia sorghi

Compatible interaction

Gene expression

RT-qPCR

\begin{abstract}
Differential display analyses of expressional modulations occurring in plant-microbe interactions provide valuable information about the physiological changes and underlying genetic factors and mechanisms involved in host resistance and susceptibility to disease. We carried out a differential display analysis study in the compatible interaction of $Z$. mays and $P$. sorghi and identified 98 Transcript Derived Fragments (TDFs) as expressional modulation showing tags. 72 TDFs were cloned and sequenced. Sequence database similarity searches revealed that there is at least one close matching GenBank record for each TDF. Compiled results showed that approximately half of the TDFs were derived from genes with known functions, about a half of which are known to display expressional modulations in plantmicrobe interactions. CA, BiP2, An2, ARP1 and ASR3-like protein encoding sequence similar TDFs constituted the prominent examples of this group. A large proportion of TDFs were found to be similar to uncharacterized/hypothetical protein encoding GenBank records. RT-qPCR primers were designed for Bip2, CA, cALDH, ARP and Arpp3 genes to verify their observed expressional modulations, which were generally confirmed except for CA. Although a limited number of TDFs were characterized, overall, the results provide an overview to the expressional modulation showing genes in the compatible interaction of the studied pathosystem.
\end{abstract}




\section{Giriş}

Bitki savunma yanıtları esas olarak hücresel düzeyde, innate (doğuştan gelen) immünite formunda etkin olup, önceden oluşturulan ve sonradan aktive olan (indüklenen) mekanizmalarla lokal ve sistemik olarak sağlanmaktadır. Pasif ve indüklenen direnç olarak ta tanımlanan bu mekanizmalardan, pasif direnç hücre duvarından vaks örtüsüne, trikomlara ve antimikrobiyal bileşiklere geniş bir yelpazede fiziksel ve biyokimyasal bariyerlerden oluşmaktadır (Dickinson 2005; Bigeard ve ark. 2015). Özelleşmiş patojenler bu fiziksel ve biyokimyasal bariyerleri aşarak enfeksiyon oluşturabilmekte, bu aşamada, çok katmanlı indüklenen savunma yanıtlarının etkinliğine bağlı olarak sonuç, hastalık gelişimi veya konukçu direnci olabilmektedir.

Bitkilerin patojen saldırılarına karşı koymasında fonksiyonel olan (biri elisitörle, diğeri efektörle) indüklenebilir iki savunma katmanı ayırt edilmektedir. Bir ilk basamak savunma katmanını mikrobiyal temasla aktive olan plazma membranı reseptörleri, PRR'ların, (Pattern Recognition Receptors) patojen orijinli (elisitörleri) moleküler motifleri, PAMP'lar1 (Pathogen-Associated Molecular Patterns) algılamasıyla indüklenen, PAMP ile tetiklenen immünite, PTI oluşturmaktadır (Jones ve Dangl 2006). Bazal direnç veya onun bir parçası olarakta tanımlanan bu ilk basamak savunma yanıtını patojenler kodladıkları efektörlerle baskılayarak hastalık oluşturabilmektedirler. Efektörle tetiklenen duyarlılık, ETS (Effector-Triggered Sensitivity) olarak tanımlanan durum, efektörü direk veya dolaylı olarak (guard üzerinden) tanıyan bitki direnç geni proteini bulunması (ortaya çıkış1) durumunda, bir diğer savunma katmanı aktive olmaktadır. Efektörle Tetiklenen İmmünite, ETI (Effector-Triggered Immunity) (Jones ve Dangl 2006) denen bu savunma katman1, PTI sonrası veya birlikte bitki savunmasını sağlamaktadır. ETI, patojen ve konukçu genoptiplerinde, karşıllklı gen çiftlerince kodlanan spesifik ürünler arasında, sadece özgün tanıma durumunda tetiklenen bir savunma yanitı olup, alternatifi durumlarda, hastalık gelişimi/konukçu duyarlılığ 1 ortaya çıkmaktadır. Bir genetik motif olarak bu savunma yanıt1, Flor tarafindan 1942'de gene-karşı-gen (gene-for-gene) interaksiyonu olarak tanımlanmıştır (Flor 1971). ETI yanıtı, infeksiyon bölgesinde lokalize hücre ölümüyle patojen gelişiminin sınırlandırıldığ 1 Hipersensitif Reaksiyon (HR) (Greenberg 1997; Heath 2000) ve aktive edilen diğer savunma yanıtlarıyla, PTI'ya göre çok daha etkin, yükseltilmiş spesifik bir konukçu direnci sağlamaktadır (Gebrie 2016).

Bitkilerin patojenleriyle temas1 ve kolonize edilmeleri, genel olarak genom ekspresyonu değişimleriyle orkestra edilen fizyolojik, metabolik, yapısal birçok modifikasyonun da eşlik ettiği konukçu savunma veya duyarlılığını ortaya çıkarmaktadır. İnteraksiyona giren her iki organizmada gerçekleşen transkripsiyonel modülasyonların karakterizasyonu, hastalık mekanizmalarından muhtemel hastalık kontrol noktalarının tanımlanmasına, birçok yönden katkı sağlayan çalışmalar olmaktadır (Rezzonico ve ark. 2017). Mikroarrayden derin transkriptom sekanslamaya bir dizi transkriptom analiz tekniği, patosistem transkriptomlarının karakterizasyonunda kullanılmaktadır. Elde edilen bilgiler, konukçu organizmanın mikrobiyal sinyalleri algılamasından fizyolojisinde gerçekleşen değişimlerin duyarlı ve dirençli genotiplerde karakterizasyona, konukçu duyarlılığı ve savunma yanıtlarının indüksiyonunda rol oynayan mekanizmaların belirlenmesine kadar geniş bir yelpazede bilgiler sağlamaktadır (Wise ve ark. 2007; Lodha ve Basak 2012). Jel esaslı DDRT-PCR (Liang ve Pardee 1992)
cDNA-AFLP (Bachem ve ark. 1996) teknikleri, diğer taraftan kapsamlı ve büyük ölçekli metotlara ekonomik alternatifler olarak kullanım bulmakta ve ön sekans bilgisi olmadan tüm genomlara uygulanabilmektedir.

P. sorghi, tropik ve subtropik bölgelerde yaygın görülen ve infeksiyon düzeyine bağlı olarak \%40'a varan verim kayıplarına neden olan önemli bir problemdir (Sahah ve Dillard 2006). Pasın farklı ırklarına savunmayı sağlayan çok sayıda direnç geni tanımlanmış (Hulbert 1997) ve pas kontrolünde kullanılmakla birlikte, patojen virülansı ve konukçuda gerçekleşen olaylarla ilgili bilgiler sınırlıdır. Bu alanda yapılan çalışmalarda uyumsuz (incompatible) interaksiyonları ve konukçu direnç mekanizma ve faktörleri daha fazla ilgi görmektedir ve uyumlu (compatible) interaksiyonlar az sayıda çalışmaya konu olmuştur. Duyarlı genotipte gerçekleşen olayların karakterizasyonu, hastalık gelişimi, konukçu metabolizma ve fizyolojisinde gerçekleşen olayların belirlenmesi açısından önemlidir (Rezzonico ve ark. 2017). Mevcut çalışma, P. sorghi-Z. mays patosistemi uyumlu interaksiyonunda ekspresyonu pas inokülasyonuyla modülasyon gösteren mRNA etiketlerinin DDRT-PCR tekniğiyle tanımlanması, transkripti oldukları genlerin belirlenerek interaksiyonda rollerinin değerlendirilmesi amaciyla gerçekleştirilmiştir.

\section{Materyal ve Yöntem}

\subsection{Biyolojik materyal ve RNA izolasyonu}

Çalışmada pas izolatı T09 ve üzerinde virülent olduğu A188 inbredi kullanılmıştır. İki set halinde yetiştirilen 7 günlük A188 fideleri kontrol ve uygulama grupları halinde tasnif edilmiş, uygulama grupları yeni hasat edilmiş pas sporları, kontrollerine sadece steril saf su uygulaması yapılmıştır. Tüm bitkiler aynı koşullarda bir gecelik soğuk nem çemberinde $(\% 95<$ nem, $\sim 24^{\circ} \mathrm{C}$ ) tutularak enfeksiyon başlatılmış ve uygulama sabahında bitkiler $\sim 27^{\circ} \mathrm{C}$ ve $\sim 16 \mathrm{~h} / 8 \mathrm{~h}$ gündüz/gece fotoperiyodunda büyümeye bırakılmıştır. Kontrol ve uygulama bitkilerinden ikişer fidenin 2. yaprak $\sim 7 \mathrm{~cm}$ uç kısmı ( 100 mg) 0, 12, 24, 48, 72 , 96 ve 120. saatlerinde örneklendi, sıv1 azot içinde dondurularak $1.5 \mathrm{ml}$ tüp içinde toz haline getirildi ve tav edilmeden $1 \mathrm{ml}$ RNAzol (MRC) eklenip karıştırılarak homojenatlar hazırlandi.

DDRT-PCR, materyal örnekleri, kapsanan süre aralığı münferit homojenatlarından, kontrol, K, (0-120 h), T1 (12-48 h) ve T2 (72-120) eşit miktar materyal birleştirmeleriyle (pool edilerek) hazırlanmıştır: Birleştirilmiş materyallerden total RNA izolasyonları sağlanan MRC protokolüne göre gerçekleştirildi (Südüpak 2014). Pellet büyüklüğüyle orantılı olarak 50-100 $\mu 1$ DEPC suyu içinde çözülen örneklerin konsantrasyonları nanodropla ölçüldü ve yaklaşı $100 \mathrm{mg}$ dokudan $60 \mu \mathrm{g}$ total RNA elde edildi, saflık ise, 1.8-2.0 bulundu.

\section{2. $D D R T-P C R$}

RNA örneklerinden cDNA sentezi, münferit ve ortak olarak hazırlanan iki karışım kombine edilerek gerçekleștirildi: Münferit RT reaksiyonlarının RNA-primer karışımları, $37 \mu 1$ DEPC muameleli-dd $\mathrm{H}_{2} \mathrm{O}$ içinde $20 \mu$ total RNA $(\sim 8 \mu \mathrm{g})$ ve 3 $\mu \mathrm{l}$ oligo-d(T) $)_{11}$ primeri kombine edilerek $60 \mu \mathrm{l}$ hacimde oluşturulmuş ve 5 dakika $65^{\circ} \mathrm{C}$ 'de inkübasyonu takiben 10 dakika $37^{\circ} \mathrm{C}$ 'ye soğutmayla hazırlandı. Bu karışıma, $40 \mu \mathrm{l}$ ortak sentez karışımı [bileşimi $20 \mu \mathrm{l}$ X Fermentas RT- $\mathrm{H}^{-}$tamponu, 200 U Ribolock (Thermo-Fermentas), $10 \mu \mathrm{l}$ dNTP karışımı (2

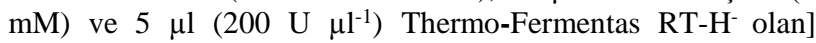


eklenerek teşkil edilen $100 \mu$ hacimde ve 60 dakika $42^{\circ} \mathrm{C}^{\prime}$ de inkübasyonla cDNA sentezleri gerçekleştirildi. Sentez sonrası, reaksiyonlar 5 dakika $95^{\circ} \mathrm{C}$ 'ye isitılip enzim inaktive edilerek $-20^{\circ} \mathrm{C}$ 'de muhafaza edildi. Sentez ürünlerinin 1:1 seyreltmeleri $2 \mu$ 'si mRNA-DDRT-PCR reaksiyonlarında kalıp olarak kullanıldı.

Münferit DDRT-PCR reaksiyonları $15 \mu$ l hacimde standart protokol izlenerek hazırlanmıştır. Reaksiyon karışımlarında amplifikasyon, $94^{\circ} \mathrm{C}$ 'de 3 dakika başlangıç denatürasyonu sonrasında her biri $94^{\circ} \mathrm{C}$ 'de 30 sn denatürasyon, $42^{\circ} \mathrm{C}$ 'de $30 \mathrm{sn}$ primer bağlanması, $72^{\circ} \mathrm{C}$ 'de 1 dakika zincir uzatımından oluşan 35 döngü PCR ve $72^{\circ} \mathrm{C}^{\prime}$ de 5 dakika son uç doldurmadan oluşan programla gerçekleștirilmiștir. Reaksiyon karıșımlarına sonra yükleme boyası eklenmiş, $94^{\circ} \mathrm{C}$ 'de $3-4$ dakika bekletilerek amplikonlar denatüre ve konsantre edilmiștir. Takiben örnek 5 $\mu$ l'si 75 W'ta $10-15$ dakika ön yürütmeyle $45-50^{\circ} \mathrm{C}$ 'ye 1 sitılmış $\% 6$ 'llk denatüre edici 0.5X TBE PAGE (19:1) jellerinde $50 \mathrm{~W}$, $\sim 50^{\circ} \mathrm{C}$ 'de $90-100$ dak. yürütülmüștür. Yürütme boyası, $\mathrm{XC}$ jel tabanına $\sim 15 \mathrm{~cm}$ mesafeye gelince koşturma durdurularak jel soğutulup açılmış ve 1 litre \%10'luk asetik asit solüsyonunda 20-30 dakika fikse edilerek gümüş boyamayla amplikonlar jel içinde görünür hale getirilmiştir.

\subsection{TDF'lerin klonlanmast ve sekanslanmast}

Ekspresyonel değişim gösteren bandlar jellerden toplanarak elüt edildi. Elüt $3 \mu \mathrm{l}$ 'siyle $25 \mu \mathrm{l}$ re-amplifikasyon PCR'ları DDRT-PCR deneylerindeki konsantrasyonlar ve parametrelerle gerçekleştirildi. PCR ürünleri purifiye edilerek klonlanmaları, linear pTZ57 veya pUC18 T-vektörlerinden biri içine ligasyon ve $E$. coli JM107 hücrelerine transformasyonla gerçekleştirildi. Rekombinant kolonilerden duruma göre plazmid izolasyonuyla veya koloni-PCR ile etiketler hazırlandı ve hizmet alımıla sekanslatıldı. Sekansların benzerlik taramaları genbankası veri tabanlarında (NCBI, maizeGDB, vb.) gerçekleştirildi ve en yakın benzerleri dikkate alınarak gen ve fonksiyon tanımlamaları yapıldı.

\section{4. $R T-q P C R$}

RT-qPCR çalışmaları için materyal, daha önce tanımlandığı şekilde, iki biyolojik tekrar olarak kontrol gruplarıla birlikte yetiştirildi. Fideler yeni toplanmış pas sporlarıyla inoküle edilerek, $0,6,12,24,48,72,96$ inokülasyon sonras1 saatlerde yukarıda tanımlandığı gibi örneklendi ve münferit örneklerden RNA izolasyonları $100 \mathrm{mg} \mathrm{ml}^{-1}$ ölçeğinde gerçekleştirildi. RNA'nın DNaz I muamelesi, oligo(dT) primeriyle cDNA sentezi ve diğer manipülasyonlar daha önce tanımlandığ 1 şekilde, aynı enzim ile diğer bileşenler ve protokoller kullanılarak gerçekleştirildi. İki aşamalı qPCR çalışmalarının RT-qPCR aşamasında, AMPLIQON Real Q-Plus/WO ROX 2x Green karışımı kullanıldı. Reaksiyonlar, $10 \mu$ Real Q plus ile birlikte her biri $10 \mathrm{pmol}$ ileri/geri gen spesifik primerler ve 50 defa seyreltilmiş cDNA kalıbının $3 \mu$ 'si $6 \mu$ dd $\mathrm{H}_{2} \mathrm{O}$ içinde kombine edilerek $20 \mu \mathrm{l}$ hacimlerde hazırlandı. RT-qPCR programı; $95^{\circ} \mathrm{C}$ 'de $15^{\prime}$ HotStart DNA polimeraz, TEMPase aktivasyonunu takiben, her biri, $94^{\circ} \mathrm{C}$ 'de 20 sn denatürasyon, $59^{\circ} \mathrm{C}$ 'de 20 sn primer bağlanması ve $72^{\circ} \mathrm{C}$ 'de 30 sn zincir uzatımı sıcaklık ve süre segmentlerinden teşkil edilen 40 döngüden oluşmuştur. Qiagen Rotor-Gene Q, Real-Time termal döngüleyicide önerilen koşullarda ve zincir uzatımı sonunda kit bileşimindeki (SYBR) Green boyasıyla reaksiyonların PCR ürünü sentez kinetiği monitör edilmiş ve eşik döngü değeri $(\mathrm{Ct})$ hesaplanmaları yapılmıştır. ZmAktin1 (J01238.1) geninin internal kontrol ve normalizasyonda kullanıldığ çalışmalarda, ölçülen hedef gen kalibratör ve uygulama $\mathrm{Ct}$ değerleri, delta-deltaCt metoduyla (Livak ve ark. 2001), ayn1 deneyde paralel ölçülen referans gen $\mathrm{Ct}$ değerleriyle normalize edilerek kalibratöre göre relatif ekspresyonları hesaplandı.

Çalışmada tanımlanan etiketlerden bitki-mikrop interaksiyonlarında rol oynadığı düşünülen beş gen ( $\mathrm{ZmCA}$, (NM_001154374.1), ZmARP1 (EU964946.1), ZmBip2 (NM_001112424.1), ZmcALD (AF348412.2), ZmArpp3 (NM_001111919.1) ve bir referans genden, ZmAktin1 (J01238.1), orijine olan transkriptlerin kodlama veya 3' UTR bölgesinde hedef segmentleri amplifiye eden primer çiftleri web tabanl1 Primer3plus (sourceforge.net/projects/primer3) programıla tasarlandı ve çalışmada kullanıldı (Çizelge 1).

\section{Bulgular}

Gerçekleștirilen mRNA DDRT-PCR çalışmasında, 27 primer kombinasyonuyla ekspresyonu modülasyon gösteren 98 TDF tanımlandı ve klonlandı. Elde edilen 72 TDF sekansiyla yapılan GenBankası taramaları, 32 etiket sekansın fonksiyonu bilinen kayıtlara (Çizelge 2, Şekil 1), diğer bir 31 etiketin ise, karakterize edilmemiş/hipotetik protein kodlayan sekanslara benzerlik olduğunu göstermiştir. Kalan 9 etiketten, biri $P$. graminis Cullin 1 mRNA sekansina benzer, ikisi mısir mtDNA, biri mısır ctDNA sekansına benzerlik gösteren ve diğerleri de bakteriyel sekanslara benzer bulunmuştur. Tanımlanan genlerin bir gruplandırılması yüzdeleriyle Şekil 1'de grafik olarak verilmektedir.

Çizelge 1. Seçilen genlerin ekspresyon teyitlerinde kullanılan RT-qPCR primerleri.

Table 1. RT-qPCR primers used in expressional validation studies of the selected genes.

\begin{tabular}{|c|c|c|c|}
\hline Genler & Primer sekansları, 5’ $\rightarrow$ 3' (sırasıyla, İleri / Geri primer) & Ürün (bç) & Kullanılan primer bağlanma sıcaklığı $\left({ }^{\circ} \mathbf{C}\right)$ \\
\hline \multirow{2}{*}{ ZmActin1 } & TTTAAGGCTGCTGTACTGCTGTAGA & \multirow{2}{*}{120} & \multirow{2}{*}{59} \\
\hline & CACTTTCTGCTCATGGTTTAAGG & & \\
\hline \multirow{2}{*}{$Z m A R P$} & AATCGCCAATAAGCAACAAC & \multirow{2}{*}{184} & \multirow[b]{2}{*}{59} \\
\hline & GCCCAAACTAGGATGGAAAT & & \\
\hline \multirow[b]{2}{*}{$Z m C A$} & AGTTCCTCACATGGAAAAAGTGAAA & \multirow[b]{2}{*}{195} & \multirow[b]{2}{*}{59} \\
\hline & TGGGCGATTGTTGATCCGGT & & \\
\hline \multirow{2}{*}{ ZmBip2 } & TGTTTAGGAGGGAGGGTGGT & \multirow{2}{*}{135} & \multirow{2}{*}{59} \\
\hline & CACTGCAATGCGAATCCTCT & & \\
\hline \multirow[b]{2}{*}{ ZmArpp3 } & CAATGATGGTGAGCGGAGGT & \multirow{2}{*}{219} & \multirow{2}{*}{59} \\
\hline & AGGTTCACAGACAGGACAGC & & \\
\hline \multirow[b]{2}{*}{$Z m c A L D H$} & TACAAGATGAGCGGGTTCGG & \multirow[b]{2}{*}{120} & \multirow{2}{*}{59} \\
\hline & ACAGGATGAGGTCGGTCAGA & & \\
\hline
\end{tabular}


Çizelge 2. Belirli bir fonksiyonla ilişkilendirilebilen TDF'lerin listesi. Tabloda en yakın sekans benzerleriyle birlikte ekspresyon profilleri ve diğer ilgili bilgiler listelenmektedir.

Table 2. The list of TDFs having close similarity to the genes with known functions. Accession numbers of the closest matching GenBank record, expression profiles and other related information are given in the table.

\begin{tabular}{|c|c|c|c|c|c|c|c|}
\hline TDF & Uzunluk & Aksesyon no & En yakın sekans benzeri & E-değeri & \multicolumn{3}{|c|}{ Ekspresyon $^{\S}$} \\
\hline \multicolumn{5}{|c|}{ Stres, savunma, sinyal iletimi, büyüme-düzenleme iliş̧ili etiketler } & $\mathbf{K}$ & T1 & T2 \\
\hline DD1 & 97 & XM_008647554 & Z.m. ABA stres-olgunlaşma protein $3 \mathrm{mRNA}$ & $8 \mathrm{e}-99$ & $*$ & I & $\mathrm{R}$ \\
\hline DD2 & 52 & XM_008657861 & Z.m. Loricrin-benzeri transkript var. X2, mRNA & $6 e-16$ & + & $\mathrm{R}$ & $\mathrm{R}$ \\
\hline DD3 & 138 & EU954250.1 & Z.m. SRC2 mRNA & $1 e-58$ & $*$ & I & $\mathrm{R}$ \\
\hline DD4 & 216 & XM_008659761 & Z.m. Filamentasyon sicaklığa duyarlı $\mathrm{H} 2 \mathrm{~A}$ & $3 e-123$ & + & $\mathrm{R}$ & I \\
\hline DD5 & 147 & EU964946.1 & Z.m. Oksinle baskılanan protein mRNA & 0.0 & $*$ & I & I \\
\hline DD6 & 45 & EU973052.1 & Z.m. Büyüme düzenleyici faktör mRNA & $3 e-18$ & $*$ & * & $*$ \\
\hline DD7 & 114 & XM_008653311 & Z.m. Gamma yanıtı I protein mRNA varyantı X8 & $3 e-30$ & + & $\mathrm{R}$ & $\mathrm{R}$ \\
\hline DD8 & 199 & XM_008650278 & Z.m. Kauren sentaz $2(A n 2)$ mRNA varyantı X1 & $9 e-21$ & $*$ & I & $\mathrm{R}$ \\
\hline DD9 & 71 & XM_008669566 & Z.m. TPR motif içeren protein mRNA varyantı X1 & $5 e-23$ & + & $\mathrm{R}$ & $\mathrm{R}$ \\
\hline DD10 & 83 & XM_008662088 & Z.m. TPR içeren karakterize edilmemiş protein, mRNA & $4 e-13$ & + & $\mathrm{R}$ & I \\
\hline DD11 & 140 & NM_001152569 & Z.m. Tetratrikopeptid tekrar protein mRNA & $1 e-45$ & - & I & $\mathrm{R}$ \\
\hline DD12 & 76 & EU966630.1 & Z.m. Tetratrikopeptid tekrar protein mRNA & $3 e-32$ & - & I & $\mathrm{R}$ \\
\hline DD13 & 169 & XM_008675810 & Z.m. Auxilin-ilişkili protein 1-benzeri mRNA & $6 e-09$ & + & $\mathrm{R}$ & $\mathrm{R}$ \\
\hline DD14 & 123 & NM_001112424 & Z.m. Bip2 (ER şaperonu) mRNA & $4 e-30$ & + & I & I \\
\hline DD15 & 176 & NM_001157006 & Z.m. Ribozom geri dönüşüm faktörü (RRF) mRNA & $3 e-11$ & + & $\mathrm{R}$ & $\mathrm{R}$ \\
\hline DD16 & 75 & NM_001111919 & Z.m. Asidik ribozomal protein P3 (arpp3) mRNA & $1 e-63$ & $*$ & * & $*$ \\
\hline DD17 & 120 & EU968527.1 & Z.m. $17.5 \mathrm{kDa}$ sinıf II HSP mRNA & $3 e-13$ & $*$ & * & $*$ \\
\hline DD18 & 146 & XM_008646106 & Z.m. U5 küçük nüklear ribonükleoprotein mRNA & $1 \mathrm{e}-48$ & + & I & $\mathrm{R}$ \\
\hline DD19 & 96 & DQ417753.1 & Z.m. B73 serin/treonin kinaz içeren gDNA sekansı & $8 e-36$ & + & $\mathrm{R}$ & $\mathrm{R}$ \\
\hline DD20 & 102 & NM_001111704 & Z.m. Metile bağlanan domain protein mRNA & $9 e-46$ & $*$ & * & $*$ \\
\hline \multicolumn{8}{|c|}{ Fotosentez, metabolizma ve transport ilişkili etiketler } \\
\hline DD21 & 136 & EU969568.1 & Z.m. Rubisco kü̧̈ük alt birim (rbcS-m3) geni & $4 e-32$ & + & $\mathrm{R}$ & $\mathrm{R}$ \\
\hline DD22 & 294 & EU965446.1 & Z.m. Fotosistem II $22 \mathrm{kDa}$ protein mRNA & $4 e-74$ & + & $\mathrm{R}$ & $\mathrm{R}$ \\
\hline DD23 & 270 & NM_001111758 & Z.m. Fotosistem II alt birim PsbS1 mRNA & $5 e-99$ & + & $\mathrm{R}$ & $\mathrm{R}$ \\
\hline DD24 & 95 & AF467541.1 & Z.m. Treonin dehidrataz mRNA (kloroplast formu) & 0.0 & + & + & $\mathrm{R}$ \\
\hline DD25 & 100 & NM_001154374 & Z.m. Karbonik anhidraz (CA) mRNA sekans1 & $1 e-56$ & $*$ & I & $\mathrm{R}$ \\
\hline DD26 & 66 & XM_008666956 & Z.m. Nikotinanamid sentaz 3-benzeri mRNA sek. & $2 \mathrm{e}-34$ & $*$ & I & I \\
\hline DD27 & 59 & AF348412.2 & Z.m. cALD (RFC2) mRNA & $9 e-39$ & + & I & I \\
\hline DD28 & 81 & $\mathrm{X} 15642.1$ & Z.m. Fosfoenol pürivat (PEP) karboksilaz mRNA & $2 \mathrm{e}-39$ & + & $\mathrm{R}$ & $\mathrm{R}$ \\
\hline DD29 & 146 & XM_008679140 & Z.m. Siklik nükleotid kontrollü iyon kanalı mRNA & $2 \mathrm{e}-60$ & + & $\mathrm{R}$ & $\mathrm{R}$ \\
\hline DD30 & 136 & EU954542.1 & Z.m. ATP sentaz C zinciri mRNA's1 & $6 e-47$ & - & - & I \\
\hline DD31 & 171 & GU075813.1 & Z.m. ATP sentaz F0 alt ünitesi 6 (atp6) mRNA & $1 e-72$ & + & I & + \\
\hline DD32 & 96 & X80820.1 & Z.m. ABP1 mRNA (aktin-depolimerizasyon faktörü) & $7 e-07$ & + & $\mathrm{R}$ & $\mathrm{R}$ \\
\hline
\end{tabular}

"yok", “*”; kaydedilmemiş bilgi.

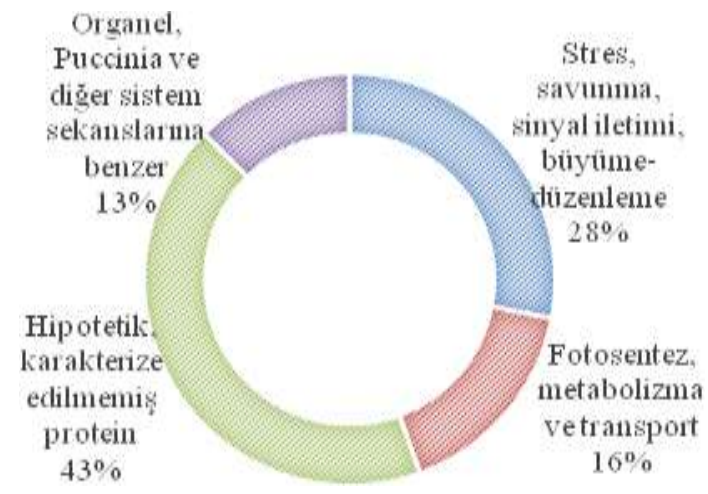

Şekil 1. Tanımlanan genlerin gruplandırılmaları.

Figure 1. Functional groupings of the identified genes. 
Belirli fonksiyonlarla ilişkili olan etiketlerin önemli bir bölümünün bitki-patojen interaksiyonlarında rol oynadığı veya ilişkili olduğu bilinen mesajlardan orijine oldukları tespit edilmiştir (Çizelge 2). Bunlar arasında, biyotrofik patojenlere yanıtta rol oynayan Salisilik Asit (SA) ile savunma yanıtında (SABP3 olarak) görev aldığ1 bilinen (kloroplast enzimi) karbonik anhidraz, Bip2 proteini, Gibberellik Asit (GA) sentez yolu enzimi ent-kaurene sentaz 2, yine interaksiyonlarda rol oynayan oksinle baskılanan ve absisik asit stres-olgunlaşma proteinleri bulunmaktadır. Yine bitki-mikrop interaksiyonlarında ekspresyonu değişim gösteren sitoplazmik aldehit dehidrogenaz (RF2C), tetratrikopeptid, büyüme düzenleyicisi faktör (GRF1) kodlayan gen sekansı homologları $\mathrm{da}$, bu tip genlerin diğer örnekleridir. Benzer olarak, sıcaklık ve soğuk gibi diğer streslerle ilişkili olduğu bilinen asidik ribozomal protein P3, SRC2, gamma yan1t1 I protein, nikotinanamid sentaz 3, axillin ve kinesin benzeri sekanslarda tanımlanan etiketler arasındadır (Çizelge 2).

Bitki-patojen interaksiyonlarında rol oynadığı düşünülen altı genin $(C A, A R P, B i p 2, A r p p 3$ ve $c A L D H)$ ekspresyonu Çizelge 1'de verilen gen spesifik primer çiftleriyle RT-qPCR deneylerinde çalışıldı. Normalize edilmiş relatif değişim değerleri ve bunlardan hazırlanan grafikler, genel olarak tespitlerinde gözlenen ekspresyonel değişimi doğrulayan sonuçlar ortaya koymuştur (Şekil 2). Karbonik anhidraz etiketinin tarama jelinde gözlenen T1'de indüksiyon T2'de represyon yerine, kontrol hariç tüm $P s$ uygulaması (6-96 h) örneklerinde düzeyi \%80'leri bulan bir represyon RT-qPCR teyitlerinde gözlenmiştir (Şekil 2a). Bip2 ve $A L D H$ ekspresyonları, sırasıyla 12 . ve 48. saatlerde 20 katın üzerinde maksimum indüksiyon seviyelerinin gözlendiği tek tepeli profillere sahiptir (Şekil 2b). Arpp3 ekspresyonu, 2 kat indüksiyon etrafinda dar bir aralıkta artı̧̧ azalışlar gösteren, 96. saatte, 3.5 kat relatif indüksiyon ile karakterize edilen bir değişim profiline sahiptir. ARP1 ekspresyonu ise 12. ve 48 . saatlerde sırasıyla tepe değerleri 2.2 ve 3.9 kat indüksiyon olan, çok daha heterojen bir değişim profili sergilemiştir (grafikleri verilmemiştir).

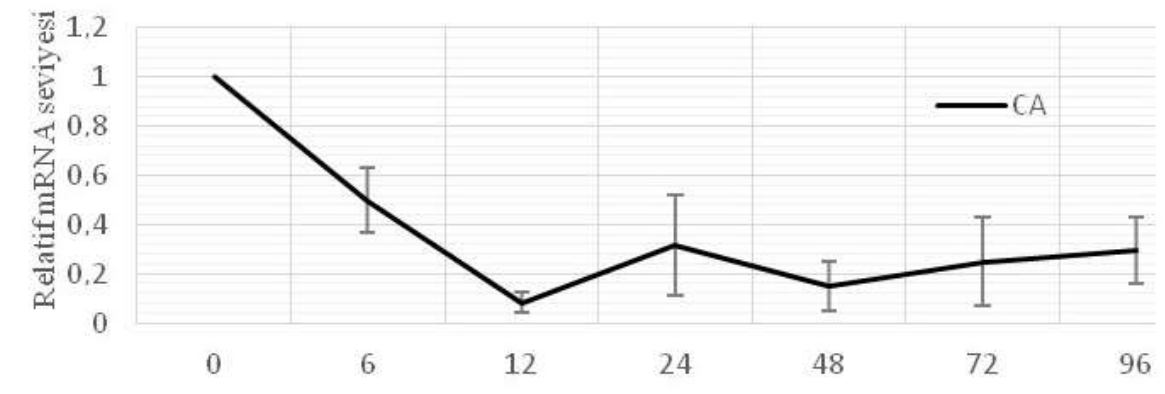

$P s$ inokülasy onu sonrası saatler

(a)

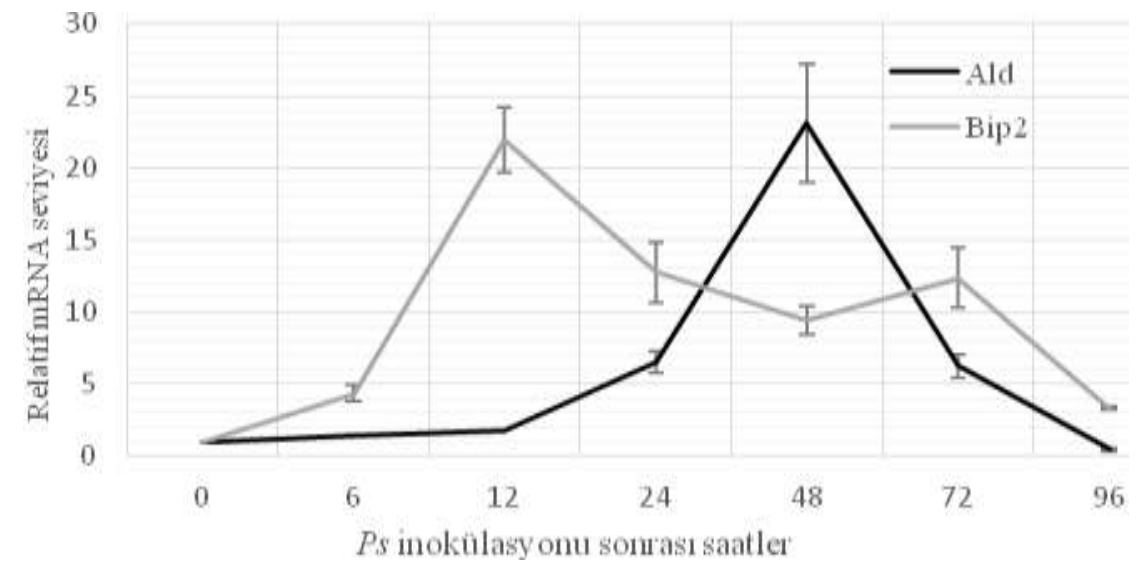

(b)

Şekil 2. RT-qPCR deneylerinde ölçülen relatif mRNA seviyesi grafikleri: (a) $Z m C A$ (b) $Z m c A L D H$ ve $Z m B i p 2$. İki biyolojik tekrarın iki teknik tekrar halinde çalışıldığı RT-qPCR deneylerinde ölçülen Ct değerleri, referans gen, ZmActinl, ekspresyonuyla normalize edilerek kontrole göre hesaplanan relatif (kat) ekspresyon değerleri standart hatalarıla birlikte grafikte verilmektedir.

Figure 2. Graphs of relative mRNA levels measured via RT-qPCR experiments: (a) ZmCA (b) ZmcALDH and ZmBip2. All experiments were carried out as biological duplicates each with two technical replicates. Computed $\mathrm{Ct}$ values were normalized to the expression level of ZmActin1 and expressed as the average fold change at each time point with relative to the control. Bars represent standard errors. 


\section{Tartışma ve Sonuç}

Bitki-patojen interaksiyonlarında transkriptom çalışmaları her iki organizmada ve ara yüzde gerçekleşen olayların karakterizasyonu, konukçu direnci/duyarlılığında rol oynayan faktörlerin belirlenmesine genom ölçeğinde katkılar sağlamaktadır (Kazan ve ark. 2001; Lodha ve Basak 2012; Rezzonico ve ark. 2017). Paraleli çalışmalara benzer olarak mısır-Puccinia sisteminde birkaç çalışma yapılmıştır. Wang ve ark. (2012) Affimetrix misir GeneChip ile misir-Puccinia polysora patosisteminde ekspresyonu modülasyon gösteren 532 prob tanımlamış, genel olarak, biyotik stres yanıtlarında rol oynayanların indüklendiği, abiyotik streslere yanıtı ilişkililerin ekspresyonlarının ise, baskılandığı gözlemlenmiştir. Mısır- $P$. sorghi sistemi kompatibıl ve inkompatibıl interaksiyonlarında gerçekleştirilen cDNA-AFLP çalışmasında 310 TDF'in sekans karakterizasyonu yapılmıştır (Südüpak 2014). Fonksiyonu bilinen gen sekanslarına benzerlik gösteren TDF'lerin büyük çoğunluğunun bitki-patojen interaksiyonlarında rol oynayan genlerden orijine olduğu bulunmuştur. Gerçekleştirilen DDRT-PCR çalışmasında tanımlanıp sekansı belirlenen 72 TDF'ten fonksiyonu bilinen genlere benzerlik gösterenlerin önemli bir bölümü de biyotik stresle ekspresyonu modülasyon gösteren genlerden oluşmaktadır. Kloroplast formu karbonik anhidraz kodlayan, ZmCA, ER şaperon ZmBip2, ZmAn2, ZmcALD, ZmARP1, Rubisco küçük alt birimi, tetratrikopeptid motif içeren protein kodlayan genler bunların tipik örnekleridir (Çizelge 2). TDF içeriğinin yaklaşık yarısının bitki-patojen interaksiyonlarında sıklıkla tanımlananlardan oluşması, hedeflenen transkriptomun çalışmada örneklendiğini göstermektedir.

Tanımlanan $\mathrm{ZmCA}$, SA-binding protein 3 (SABP3) olarak bitki savunmasında fonksiyonel olduğu bilinen bu enzimdir. VIGS ile bir homoloğunun susturulduğu Nicotiana benthamiana genotiplerinde, Pto:avrPto kombinasyonuyla tetiklenen HR'ın baskılandığı (Slaymaker ve ark. 2002), Phytophthora infestans büyümesinin artış gösterdiği bulunmuştur. Patates-Phytophthora infestans kompatibil interaksiyonunda da, inokülasyonu takiben ilk 12-15 saat aralığında $C A$ transkripsiyonu baskılanmaktadır (Restrepo ve ark. 2005). Yu ve ark. (2012) SABP3'ün Arabidopsis te direnç reaksiyonu pozitif regülatörü olduğunu ileri sürmektedir. Misır$P s$ interaksiyonu RT-qPCR deneylerinde 6. saatten itibaren başlayan genel baskılanma durumu, yukarıda tanımlanan çalışma sonuçlarıyla paralellik göstermektedir (Şekil 2a). Bir SABP3 olarak karbonik anhidrazın çalışılan patosistem konukçu savunmasında rol oynadığı, gözlenen baskılanmanın kompatibıl interaksiyonda ortaya çıkan bir durum olduğu mevcut bilgilerle yapılabilecek bir değerlendirmedir.

Hem TDF olarak, hem de RT-qPCR teyidinde pas inokülasyonuyla ekspresyonu belirgin şekilde indüklenen (Şekil 2b) aldehit dehidrogenaz (AF348412.2, RF2C), interaksiyonda fonksiyonel olduğu düşünülen diğer bir gendir ve paraleli bulgular bir birçok yayında rapor edilmektedir: Wang ve ark. (2007) Çin üzümünde (Vitis pseudoreticulata) külleme fungusu Uncinula necator infeksiyonu sonras1 ekspresyonu indüklenen bir $A L D H$ tanımlamışlardır. Biberde CaALDH1 geninin susturulması, hidrojen peroksit birikimiyle hücre ölümü yanıtı ve $X$. campestris $p v$. vesicatoria'ya direncin azalmasına neden olmaktadır (Kim ve ark. 2015). Benzer olarak, bu enzimlerin programlı hücre ölümünde rollerine bir kanıtta, pirinç hastalık lezyonu mimik mutantında ( $c d r 2)$ yüksek seviyede ALDH proteini birikiminden gelmiştir (Tsunezoka ve ark. 2005). Arabidopsis te artırılmış ALDH1 ekspresyonu Pseudomonas syringae pv. tomato ve Hyaloperonospora arabidopsidis Noco2 infeksiyonlarına duyarlılığı azaltmaktadır (Kim ve ark. 2015). Aldehit dehidrogenazların bitki stres yanıtı yollarında, özellikle de oksidatif stres oluşturanlarda önemli olduğu değerlendirilmektedir (Singh ve ark. 2013).

Ekspresyonu indüklenen üç farklı TDF sekansı halinde tanımlanan ve RT-qPCR ekspresyon teyidi yapılan (Şekil 2b) misır Bip2 (NM_001112424.1) geni, bulgularımızla uyumlu olarak mikrobiyal enfeksiyonlar sirasında, PR protein ekspresyonu öncesinde hızlı bir şekilde indüklenen bir mesajdır (Tsunezoka ve ark. 2005; Jelitto-Van Dooren ve ark. 1999). BiPler, ER'da yanlış katlanmış proteinlere bağlanarak degredasyonlarında, ER ilişkili apoptozis sinyali düzenlenmesi ve patojenlere immünite de rol oynayan şaperonlardır. Bip2, ekspresyonunun susturulmas1, PR1 sekresyonu, SAR kurulumunu ve genel patojen direncini zayıflatmaktadır (Wang ve ark. 2005). Diğer çalışmalar, patojen infeksiyonlarında, savunmada rol oynayan moleküllerin sentezi ve salgılanmasının büyük ölçekli arttığını, bu sentez yolu ve fonksiyonel olan elemanlarının savunma yanıtlarında önemli olduğunu göstermektedir (Kørner ve ark 2015). Pirinçte artırılmış BiP3 ekspresyonu, immünoreseptörün proses edilmesi ve stabilitesini düzenleyerek Xa21 ile sağlanan dirence katk1 sağladığ1 ileri sürülmektedir (Park ve ark 2010). Bu tespitler çerçevesinde, BiP'in PCD pozitif regülatörü olduğu ileri sürülmektedir. Ayrıca, ER protein sentezi ve işleme kapasite düzenlenmesinin, bitki savunma yanıtlarında önemli olduğu, tanımlanan BiP2'nin bu sistemin bir elemanı olarak çalışılan patosistemde fonksiyonel olduğu bulgular 1şı̆̆ında değerlendirilmektedir.

Oksinle baskılanan protein (ARP, EU964946.1), pas inokülasyonuyla sınırlı bir ekspresyonel değişim gösterdiği teyit edilen diğer bir gendir. (Çizelge 2, grafiği verilmemiştir). $A R P 1$ 'in vejetatif büyümeyle hastalık direnci/savunma yanıtları arasında ikili bir role sahip olduğu ileri sürülmektedir. $A R P 1$ ekspresyonu vejetatif büyümeyi negatif düzenlerken, hastalık direncinin pozitif regülatörü olduğu ve bu iki durum arasında antagonist çalışan bir integral regülatör olduğu ileri sürülmektedir (Zhao ve ark. 2014). Tanımlanan ARP'ın fonksiyonu karakterize edilmiş olmamakla birlikte, bu bilgilerle birlikte tespit edilen ekspresyonel değişim, misır-Ps interaksiyonunda da benzer bir role sahip ve konukçu savunmasında önemli olabileceğini göstermektedir.

Ekspresyon teyidi yapılmamış olmakla birlikte, tanımlanan diğer bir gen, GA biyosentez yolu, ent-kauren sentaz 2 enzimini kodlayan $A n 2$ 'dir. $P s$ inokülasyonuyla ekspresyonu indüklenen bu gen Harris ark. (2005) tarafindan misirda Fusarium graminearum inokülasyonuyla indüklendiği bulunmuştur. GA'ların hem bakteriyal, (Xanthomonas oryzae pv. oryzae) hem de fungal (Magnaporthe oryzae) patojenlerle interaksiyonlarda pirinç savunma yanıtlarının negatif regülasyonunda görev aldığı ve konukçu duyarlılığının oluşumuna neden olduğu bilinmektedir (Qin ve ark. 2013). Pirinç gibi, misırda da (farklı enzim olmakla birlikte) fungal patojenler, Fusarium ve $P$. sorghi, enfeksiyonları, GA sentez enzimi indüksiyonuyla duyarlılık ortaya çıkışını, endojen GA seviyesini yükselterek sağlıyor olabilir. Diğer tanımlanan biyotik ve abiyotik stres ilişkili genler arasında sıcaklık şoku proteinleri, ArpP3, tetratricopeptide tekrar domein içeren proteinler ve SRC2, absisik asit-stres ve olgunlaşmayla indüklenen (ASR) proteinler, ribozom tekrar kullanım faktörü (RRF), büyüme düzenleyicisi faktörler de bulunmaktadır (Çizelge 2).

Sonuç olarak, sınırlı sayıda etiket çalışılmış olmakla birlikte, bitki-mikrop interaksiyonlarında rol oynadığı bilinen 
bir dizi genin sekans benzeri TDF tanımlanması ve bunların biyoteknolojik manipülasyonlarda kullanılabilir niteliklere sahip olması, çalışma kapsamı ve hedefi açısından önemlidir. Tanımlanan genler ve bunların muhtemel fonksiyonlarının bitkipatojen interaksiyonlarında, özellikle de mısır-mısır pası uyumlu interaksiyonunda gerçekleşen olayların moleküler arka planına ve manipülasyonlarına, önemleri ölçüsünde katk1 sağlaması beklenmektedir.

\section{Teşekkür}

Çalışma Yozgat Bozok Üniversitesi BAP projesi, 6601FBE/19-256 kapsamında sağlanan destekle gerçekleştirilmiştir.

\section{Kaynaklar}

Bachem CWB, Van der Hoeven RS, de Bruijn SM, Vreugdenhil D, Zabeau M, Visser RGF (1996) Visualization of differential gene expression using a novel method of RNA fingerprinting based on AFLP: Analysis of gene expression during potato tuber development. The Plant Journal 9: 745-53.

Bigeard J, Colcombet J, Hirt H (2015) Signaling mechanisms in PatternTriggered Immunity (PTI). Molecular Plant 8: 521-539.

Dickinson M (2005) Molecular Plant Pathology, pp. 160-168, BIOS Scientific Publishers. New York: Taylor \& Francis Group.

Flor HH (1971) Current status of the gene-for-gene concept. Annual Review of Phytopatholoy 9: 275-296.

Gebrie SA (2016) Biotrophic fungi infection and plant defense mechanism. Journal of Plant Pathology Microbiology 7: 378-384.

Greenberg JT (1997) Programmed cell death in plant-pathogen interactions. Annal Review of Plant Physiology and Plant Molecular Biology 48: 525-41.

Harris LJ, Saparno A, Johnston A, Prisic S, Xu M, Allard S, Kathiresan A, Ouellet T, Peters RJ (2005) The maize An2 gene is induced by Fusarium attack and encodes an ent-copalyl diphosphate synthase. Plant Molecular Biolology 59: 881-894.

Heath MC (2000) Hypersensitive response-related death. Plant Molecular Biology 44: 321-334.

Hulbert SH (1997) Structure and evolution of the rpl complex conferring rust resistance in maize. Annual Review of Phytopathology 35(1): 293-310.

Jelitto-Van Dooren EP, Vidal S, Denecke J (1999) Anticipating endoplasmic reticulum stress: a novel early response before pathogenesis-related gene induction. The Plant Cell 11: 1935-1944.

Jones JD, Dangl JL (2006) The plant immune system. Nature 444: 323 329.

Kazan K, Schenk PM, Wilson I, Manners JM (2001) DNA microarrays: New tools in the analysis of plant defense response. Molecular Plant Pathology 2(3): 177-185.

Kim NK, Hwang BK (2015) Pepper aldehyde dehydrogenase CaALDH1 interacts with Xanthomonas effector AvrBsT and promotes effector triggered cell death and defense responses. Journal Experimental Botany 66(11): 3367-3380.

Kørner C, Du X, Vollmer ME, Pajerowska-Mukhtar K (2015) Endoplasmic reticulum stress signaling in plant immunity - At the crossroad of life and death. International Journal of Molecular Sciencess 16: 26582-26598.

Liang P, Pardee AB (1992) Differential display of eukaryotic messenger RNA by means of the polymerase chain reaction. Science 257: 967971.
Livak KJ, Schmittgen TD (2001) Analysis of relative gene expression data using real-time quantitative PCR and the $2^{-\Delta \Delta C T}$ method. Methods 25: 402-408.

Lodha TD, Basak J (2012) Plant-pathogen interactions: What microarray tells about it?. Molecular Biotechnology 50: 87-97.

Park CJ, Han SW, Chen X, Ronald PC (2010) Elucidation of XA21mediated innate immunity. Cell Microbiology 12(8): 1017-1025.

Qin X, Liu JH, Zhao WS, Chen XJ, Guo ZJ, Peng YL (2013) Gibberellin 20-oxidase gene OsGA20ox3 regulates plant stature and disease development in rice. Molecular Plant Microbe Interactions 26: 227-239.

Restrepo S, Myers KL, Pozo OD, Martin GB, Hart AL, Buell CR, Fry WE, Smart CD (2005) Gene profiling of a compatible interaction between Phytophthora infestans and Solanum tuberosum suggests a role for carbonic anhydrase. Molecular Plant Microbe Interactions 18: 913-922.

Rezzonico F, Rupp O, Fahrentrapp J (2017) Pathogen recognition in compatible plant-microbe interactions. Scientific Reports 7: 63-83.

Sahah DA, Dillard H (2006) Yield loss in sweet corn caused by Puccinia sorghi: A meta-analysis. Plant Disease 90: 1413-1418.

Singh S, Brocker C, Koppaka V, Ying C, Jackson B, Matsumoto A, Thompson DC, Vasiliou V (2013) Aldehyde dehydrogenases in cellular responses to oxidative/electrophilic stress. Free Radical Biology Medicine 56: 89-101.

Slaymaker DH, Navarre DA, Clark D, del Pozo O, Martin GB, Klessig DF (2002) The tobacco salicylic acid-binding protein 3 (SABP3) is the chloroplast carbonic anhydrase, which exhibits antioxidant activity and plays a role in the hypersensitive defense response. The Proceedings of the National Academy of Sciences of U.S.A 99: 11640-11645.

Südüpak MA (2014) A cDNA-AFLP protocol with reciprocally arranged 2-enzyme sequential digestion and silver staining detection. Turkish Journal of Biolology 38: 260-270.

Tsunezoka H, Fujiwara M, Kawasaki T, Shimamoto K (2005) Proteome analysis of programmed cell death and defense signaling using the rice lesion mimic mutant cdr2. Molecular Plant-Microbe Interactions 18: 52-59.

Wang D, Weaver ND, Kesarwani M, Dong X (2005) Induction of protein secretory pathway is required for systemic acquired resistance. Science 308: 1036-1040.

Wang X, Wang Y, Hao W (2007) cDNA cloning and characterization of the novel genes related to aldehyde dehydrogenase from wild Chinese grape (Vitis pseudoreticulata). DNA Sequence18(1): 9-18.

Wang X, Liu T, Li C, Zhao Z (2012) Gene expression profiles in maize (Zea mays L.) leaves inoculation with southern corn rust (Puccinia polysora Underw.). Acta Physiologiae Plantarum 34: 997-1006.

Wise RP, Moscou MJ, Bogdanove AJ, Whitham SA (2007) Transcript profiling in host-pathogen interactions. Annual Review of Phytopathology 48: 457-479.

Yu M, Yun BW, Spoel SH, Loake GJ (2012) A sleigh ride through the SNO: Regulation of plant immune function by protein Snitrosylation. Current Opinion Plant Biology 15: 424-430.

Zhao Y, Li C, Ge J, Xu M, Zhu Q, Wu T, Guo A, Xie J, Dong H (2014) Recessive mutation identifies auxin-repressed protein ARP1, which regulates growth and disease resistance in tobacco. Molecular Plant Microbe Interaction 27(7): 638-654. 